\section{Kohti avartuvaa oikeudenmukaisuuskäsitystä}

Foster, Raisa, Mäkelä, Jussi \& Martusewicz, Rebecca, A. (toim.) (2018). Art, Ecojustice, and Education. Intersecting Theories and Practices. Routledge. 186 sivua.

кокооматеоs Art, Ecojustice, and Education on yhdistää 15 kirjoittajan voimin tieteen, taiteen ja pedagogiset ratkaisut. Ihmisenä kasvamisen ja yhteiskunnallisen edistyksen haastetta lähestytään oikeudenmukaisuuden näkökulmasta.

Englanninkielinen teos murtaa vallalla olevia jakolinjoja jo peruslähtökohdaltaan Oikeudenmukaisuusyhteisöksi eivät kirjan sivuilla määrity ainoastaan ihmiset vaan myös muu elämä planeetallamme.

EROON VÄLINEELLISTÄVISTÄ SUHTEISTA

Kirjan viesti on, että niin kolonialismia, rasismia, seksismiä kuin ihmiskeskeistä todellisuuskäsitystäkin yhdistää valtasuhde. Välineellistämisessä ensisijainen erotetaan toissijaisesta - subjekti objektista.

Ihmisenä kasvaminen on avain välineellistävistä suhteist eroon pääsemiseksi. Oppiminen mielletään teoksessa ennen kaikkea eettiseksi prosessiksi, jossa tunnistetaan ja haastetaan vallalla olevia kulttuurisia tapoja, tottumuksia ja normeja.

Taide ja taiteilijat saavat teoksessa pääroolin. Yhä viheliäisemmiksi käyvien tulevaisuuden sina ja monimediana. haasteiden vuoksi taiteen mahdolisuuksien esille ottaminen on erityisen tervetullutta. Taide avautuu kirjallisuutena, runoutena, grafiikkana, tanssina, teatterina, veistok-

Kirja jäsentyy kolmeen osaan, joista ensimmäisessä tunnistetaan muuttuneita yhteyksiä ja rakennetaan siltoja eri tavoin todellisuutta hahmottavien ihmisten ja ihmisryhmien sekä luonnon ja kulttuurin välille. Havahduttavin esimerkki luonnon ja kulttuurin välisen jakolinjan poistumisesta on uusi geologinen aikakausi, johon olemme sirtyneet. Antroposeeni, ihmisen aika, tarkoittaa sitä, että ihmisten vaikutuspiirin ulkopuolista luontoa ei enää ole.

Kun ymmärtää luonnon ja kulttuurin jakolinjan poistumisen, on mahdollista kytkeytyä muuhun olemassa olevaan yhä vastuullisemmin. Ihmisen ajassa tulevaisuuden laatu on meidän ihmisten käsissä enemmän kuin koskaan aiemmin maapallolla.

\section{YHTEISVAURAUS ON PERUSTA}

Toisessa osassa mielenkiinnon kohteena ovat yhteisvaurautta (commons) koskevat kysymykset. Elämän edellytysten säilyminen vaatii huomion kiinnittämistä asioihin ja ilmiöihin, joista elämä on

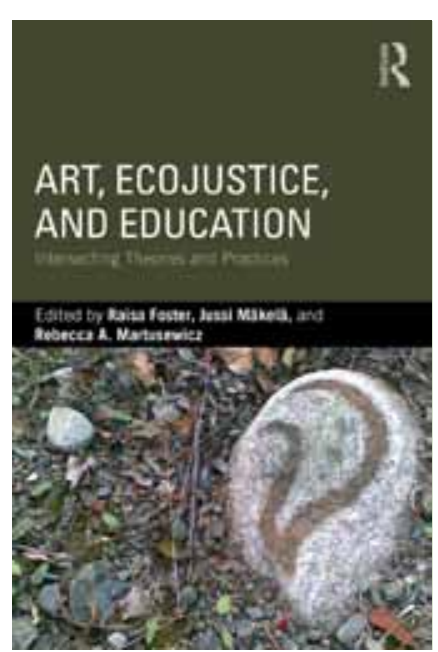

riippuvaista, mutta joita ei omista mikään instituutio eikä kukaan ihminen. Puhdas ilma, pohjavesi, elinkelpoiset maa-alueet ja vakaa ilmasto ovat esimerkkejä yhteisvaurauksista. Kirjan esimerkit tulevat Keniasta, Grönlannista a Australiasta. Ääni annetaan ennen kaikkea niille, joiden elämän edellytykset ovat alkaneet murtua yhteisvaurauksien turtuessa.

Oikeudenmukaisuuden näkökulmasta yhteisvauraude ovat monimutkainen asia, jonka ymmärtäminen edellyttää systeemistä maailmanhahmottamista. Elämä Suomessa kytkeytyy monin tavoin toisella puolella maapalloa elävien arkeen. Jaetut ajan ja paikan kokemukset eri tavoin ajattelevien ihmisten kesken voivat auttaa havahtumaan näihin kytköksiin, mikä taas on omiaan lisäämään luottamusta ja rakentamaan siltoja.

Yhteisvaurauksien

YMMÄRT ÄMINEN VAATII SYSTEEMISTÄ

MAAILMANHAHMOTTAMISTA.

MIELIKUVITUS POHJUSTAA MUUTOSTA

Teoksen kolmannessa osassa lähestytään ihmisenä kasvamisen mahdollisuuksia kiinnittämäll huomiota taiteelle tyypilliseen elementtiin: mielikuvitukseen. Kaikki uusi on ensin kuvittelun tuottama ajatus. Sitten ajatus voidaan materialisoida eli tehdä silmilla nähtäväksi ja aisteilla havaittavaksi uudeksi asiaksi.

Mielikuvituksen merkitys korostuu tulevaisuuden haasteiden haltuun ottamisessa. Yhä selvempää on, että nykyistä yhteiskunta toisintavat ratkaisut eivät varmista hyvää tulevaisuutta. Tarvitaa uudistumista, jossa haastetaan rohkeasti ne hyvän elämän tavoittelun tavat, jotka ovat osoittautuneet tulevaisuuden toivoa sammuttaviksi.

Ja vieläkin enemmän: hyötyajattelun, ihmiskeskeisyyden a välineellistämisen valtavirta kääntyy ihmistä vastaan vuos vuodelta yhä voimallisemmin. Siksi ihmisen paikka osana muuta todellisuutta on väistämätta asemoitava uudelleen. Ihmise hyvinvointi ei ole irrallaan ympäröivästä todellisuudesta, vaan ihminen on täysin riippuvainen luonnosta esimerkiksi syömänsä ruoan suhteen

\section{TAITEELLA LUODAAN UUTTA}

Teoksen viesti on kannustava. Ihmisen sisäinen uudistuminen alkaa siitä, että antaa uudistumiselle luvan. Taide auttaa, sillä se pystyy esteittä siirtämään ihmistä uudenlaisiin ajatuksiin. Se tulee lähelle ihmistä siksikin, että taiteilija asuu jokaisessa ihmisessä: taide on sitä, että antaa asioiden tapahtua.

Sisäinen uudistuminen on edellytys eheyteen ja harmoniaan pääsemiseksi ihmistä ympäröivän todellisuuden kanssa. Toivoa lisää se, että tasavertaisissa suhteissa erilaisten elämänmuotojen välillä on mahdollisuus kokea oman elämän mielekkyyttä ja merkityksellisyyttä

Teos kyseenalaistaa raikkaasti monenlaisia vallalla olevia jakolinjoja. Avaran tarkastelutapansa an siosta se kannustaa soveltamaan taiteella ryyditettyä ekologista oikeudenmukaisuuskasvatusta ajallemme tyypillisten, viheliäisten ongelmien ratkaisemiseen.

Itselleni teoksen sanoma on siinä, että se osoittaa aineettomi en asioiden maailmaa muuttavan voiman. Merkitykselliseksi, arvokkaaksi ja mielekkääksi koetun elämän ydin on kyvyssä liittää omaa elämää rikastavasti osaksi muut elämää. Tietoinen liittyminen erilaisiin merkityshorisontteihin auttaa tunnistamaan yhä arvokkaampi tarkoituksia omalle olemassaololle. Tulkinta ympäröivästä todellisuudesta rikastuu ja täyteläistyy. Itsekkyyden ja epäitsekkyyden välinen jakolinja poistuu.

Teokseen kuuluu harjoituskirjamainen verkkomateriaali, joka on kohdennettu opiskelijoille, opettajille ja oppimisen ohjaamisesta kiinnostuneille.

ARTO O. SALONEN $K T$, apulaisprofessori at-Suomen yliopisto

singin yliopisto 